\title{
IN THE MASK OF A MARTIAL ART FILM: A CHINESE FILM ADAPTATION OF WILLIAM SHAKESPEARE'S HAMLET
}

\author{
NA MÁSCARA DE UM FILME DE ARTES MARCIAIS: UMA ADAPTAÇÃO \\ CINEMATOGRÁFICA DO HAMLET DE WILLIAM SHAKESPEARE
}

Zhang Ying $^{1}$

\begin{abstract}
Resumo: O comunicado de imprensa do director chinês de cinema Feng Xiao Gang sobre The Banquet, em 2006, declara que é a primeira adaptação cinematográfica chinesa de Hamlet. Feng escolhe achinesar a peça, e entremear elementos culturais, enquadrando a peça em um filme chinês de artes marciais e aplicando a máscara Nuo chinesa e sua variação na interpretação cinematográfica dele sobre a peça. $\mathrm{O}$ enquadramento de filme de artes marciais é pesadamente apresentado como o toque cultural chinês implementado pelo director na transformação de uma peça ocidental em um filme chinês, que demonstra ser uma ferramenta efetiva para deslocar os elementos culturais ocidentais com a ideologia cultural e os princípios chineses. O uso da máscara Nuo em todo o filme é discutido com os seguintes exemplos: 1. A escolha do director de usar a mascara chinesa Nuo em sua adaptação da cena da peça-dentro-da-peça no filme, deslocando a Armadilha de Rato com sua contraparte de drama Nuo. 2. A reinterpretação do diretor sobre a hesitação e loucura de Hamlet, sua representação do Fantasma e sua abordagem simbólica da construção de personagens com a adoção de uma máscara de papel branco. 3. A transferência do diretor, do Fantasma do Velho Hamlet à simbolização da máscara esculpida em cobre. 4. A elaboração pelo diretor da caracterização através do uso da própria face como máscara. $\mathrm{O}$ enquadramento de filme de artes marciais e a adoção da mascara Nuo são as ferramentas de achinesamento no processo da adaptação cinematográfica intercultural do clássico ocidental. O sucesso do filme explorou as conexões entre as duas culturas e desafiou a transferência da cultura chinesa para uma peça ocidental.
\end{abstract}

Palavras-chave: máscara Nuo; adaptação cinematográfica; achinesamento; transferência; Hamlet

Abstract: The release of Chinese film director Feng Xiao Gang's The Banquet in 2006 declares the first Chinese Hamlet film adaptation. Feng chooses to sinicize the play and interweaving cultural elements by framing the play into a Chinese martial art film and by applying Chinese Nuo mask and its variation in his filmic interpretation of the play. The frame of martial art film is heavily featured as the Chinese cultural touch deployed by the director in the transformation of a western play into a Chinese film, which proves to be an effective tool for displacing the western cultural elements with Chinese cultural ideology and principles. The use of the Nuo mask motif throughout the film is discussed with the following examples: 1 . The director's choice of using the Chinese Nuo mask in his adaptation of the play-within-the-play scene in the film, displacing the Mousetrap with its Nuo drama counterpart. 2. The director's reinterpretation of Hamlet's hesitation and madness, his representation of the Ghost and his symbolic approach to the building of characters by adopting a white paper mask. 3 . The director's transfer from the Ghost of Old Hamlet to copper carved mask symbolization. 4. The director's building of characterization by using one's own face as the mask. The framing of martial art film and the adoption of Nuo mask are the tools of sinicization in the process of the intercultural film adaptation of the western classic. The success of the film has explored the

\footnotetext{
${ }^{1}$ Nanjing University - NJU, Nanjing, Jiangsu, P. R. China; https://orcid.org/0000-0002-3028-5487; zhangy@nju.edu.cn
} 
connections between the two cultures and challenged the transfer of Chinese culture into a western play.

Keywords: Nuo mask; film adaptation; sinicization; transfer; Hamlet

From the advent of the silent picture to the turn of the new millennium, the medium of cinema has accumulated a fairly large number of films, adapting most of Shakespeare's dramas from page to screen, developing a particular film genre-the Shakespeare film. In this film category, the greatest number of films has gone to those of Hamlet. By far, no other Shakespeare's play has produced or inspired more films than the play of Hamlet. With more than 100 years of history on screen, Hamlet has been frequently adapted into films. The latest count shows that there are nearly 50 feature-length film productions and more than 90 other films alluding to it. As Harold Bloom stated in the Western Canon that "Shakespeare is to the world's literature what Hamlet is to the imaginary domain of literary character: a spirit that permeates everywhere, that cannot not be confined" and that "you cannot confine Shakespeare to the English Renaissance any more than you can keep Falstaff within the limits of the Henry $I V$ plays, or the Prince of Denmark within the action of his drama" (49-50), Shakespeare, as well as Hamlet, have not confined themselves to the Renaissance stage, the $18^{\text {th }}$ and $19^{\text {th }}$ century theatre and the $20^{\text {th }}$ century page. They have, in a century that celebrates its popular culture, occupied a part of the central form of the popular culture - the visual culture - most notably the screen. In 2006, the first Chinese screen adaptation of Hamlet was released. Renamed as The Banquet, co-produced by Huayi Brothers and Media Asia Films, directed by renowned Chinese director Feng Xiaogang, starred by Chinese as well as international superstars like Zhang Ziyi, Ge You, Daniel Wu, Zhou Xun and Huang Xiaoming, this huge production with an estimated budget of $\$ 15,000,000$ finally led to a huge commercial success and a worldwide gross of $\$ 22,205,648$, which also aroused academic and critical interest.

Though The Banquet is the first Chinese film adaption of Hamlet, intercultural stage adaptations have long existed in China. Apart from Hamlet's frequent appearance on the modern Chinese Spoken Drama (Hua Ju) stage, the play has also made its way into Chinese traditional operas. Early in the 1920s, it was adapted into Sichuan opera Killing the Brother and Marrying the Sister-in-Law (Sha Xiong Duo Sao). After the first China Shakespeare Festival which was held in celebration of the 370th anniversary of Shakespeare's death in Shanghai from April 10th to 24th, 1986, more attempts have been made to adapt Shakespearean plays into Chinese traditional operas. The year 1994 witnessed The Prince's Revenge (Wang Zi Fu Chou $J i$ ) in Yueju operatic style. Based on Hamlet, it was adapted and performed by the Shanghai Yueju Company. In 2005, the play was again adapted into Beijing opera, still under the name of The Prince's Revenge (Wang Zi Fu Chou Ji). Though Traditional Chinese operas differ significantly from Western stage plays, both adaptations prove a successful fusion of western and Chinese culture. These two adaptations are well organized to tell Chinese traditional opera audience the story of Hamlet and have cleverly changed some Western conventions into what are appropriate to Chinese traditional opera conditions without losing much of the original, demonstrating the most outstanding artistic features of the latter. Acting, singing, dance, acrobatics, music, make-up and costumes are retained in the ritualized Chinese stagecraft. The essence of the play is transferred into the Chinese context. The characters are fully developed. This kind of intercultural performance of Shakespeare's Hamlet represents a way Shakespeare's plays are performed on local Chinese stages and to some degree contributed to promoting intercultural understanding. 
Feng Xiaogang's The Banquet is the first intercultural and inter-media adaptation of Hamlet in China. As most of the Asian Shakespearean film adaptations did, The Banquet chooses to ignore the language fidelity of the source text, yet it has the similar tragic essence and paralleling plot and characters with the original play. The period and setting of the play is relocated from the $12^{\text {th }}$ century Denmark Elsinore to the period of Five Dynasties and Ten Kingdoms of China, which lasts most decades of the $10^{\text {th }}$ century, suggesting a greater degree of historical distance. In this warring state, Emperor Li/ Claudius (Ge You) has usurped the throne through a hideous murder of his brother by pouring poison into his ear hole. The widowed Empress Wan/ Gertrude (Zhang Ziyi) marries the new Emperor only to protect herself and the Crown Prince/ Hamlet (Daniel Wu), who used to be her teenage sweetheart yet later stepson. Secretly she also plots the Emperor's death. The Crown Prince escapes the Emperor's assassin and comes back to the palace. Drawn between his present love Qing Nü / Ophelia (Zhou Xun) and old love Wan, the Prince can not bring himself to revenge. Each person in the court has his or her own plans for the throne. Intrigues are brought to a climax when the Emperor calls for a lavish night banquet, where the murderous plans are set in motion. Close reading of the film The Banquet reveals that changes have been made in the narration frame, character focus, theatrical theme and cultural ideology during the process of this intercultural film adaptation of Hamlet. According to the director Feng Xiaogang, "A thousand people will have a thousand Hamlets. It does not make much sense for him to be merely changed into a Chinese prince speaking Chinese language. Therefore, I want to have a huge shift; I want to "make love to' Shakespeare; I want to create a new Hamlet." (Feng: 2006) Feng Xiaogang's version of Hamlet, by transposition and displacement of the overall themes, by application of Chinese elements from the framework, by shifting the focus of character development, wins acceptance from the Chinese audience and makes more appeal to the oversea market.

Feng localizes his screen version of Hamlet first and foremost with his decision of framing The Banquet as a typical Chinese martial arts period film (Kungfu film). The genre of martial arts films has occupied a key position in the Chinese film history. From their birth in the late 1910s to their prosperity in the recent several decades, martial arts films have been developed into one of the hallmark genres for Chinese national films. The huge box-office success and the Academy Awards achieved by Ang Lee's Crouching Tiger, Hidden Dragon in 2001 have stirred the western film market and aroused the interest and curiosity from its audience. Martial arts films, with their stylized action or filmmaking techniques like special camera angles, montage editing, doubles, wire work, and computer-generated imageries, have created Jiang $\mathrm{Hu}$ - a illusionistic world in which the action heroes act, a world that is regulated by a chivalric code of arcane brevity, and a world that is fraught with sword fighting and blood shedding, as well as love and friendship. Taking down the evil and helping the weak are the main tasks in this world. Loyalty and intrepidity are highly esteemed in this world. In Elizabethan period and the history of English literature, Shakespeare's Hamlet rightly belongs to genre of the revenge tragedy, featuring themes and devices of revenge-seekers, ghosts, madness, delay, sinister intrigues, play-within-the-plays, multiple murders, and the realistic depiction of bloody violence onstage. The meditation upon the action and inaction of the revenge for the murder of his father and the incest with his mother contributes to the major theme of the play, and this very theme of revenge conforms to the ethics and rules of Chinese martial arts film, in which avenging for one's father is one of the major themes. This will induce a moral recognition from the target audience and it has become the ethical code and principle for the martial arts films. (Jia: 2005, 8) In this respect, it is very reasonable for the director to frame The Banquet as a Chinese martial arts film. Yet Feng Xiaogang's The Banquet differentiates itself from the traditional Chinese martial arts films in the fact that it does not employ Kungfu action and fighting plots as the main narratives of the story. Feng merely sprinkles his film with Kungfu fights and martial scenes to reach out for the action loving audience and to push the story line 
forward. By putting Shakespeare's Hamlet into the mask of a Chinese martial arts film and presenting action sequence for the audience, Feng gives his Chinese film version of Hamlet new angles of narration, nice dramatic effect, and visual magnificence, which successfully reach out for both Chinese and western spectators.

Of all intercultural adaptation strategies adopted by the director, one conspicuously noticeable motif added into the film is the application of the Chinese Nuo mask and its variation. The use of the Nuo mask motif throughout the film is heavily featured as the Chinese cultural touch deployed by the director in the transformation of a western play into a Chinese film, which proves to be an effective tool for displacing the western cultural elements with Chinese cultural ideology and principles. The present paper thus discusses the director's choice of using the Chinese Nuo mask in his adaptation of the play-within-the-play scene in the film, his reinterpretation of Hamlet's hesitation and madness, his representation of the Ghost and his symbolic approach to the building of characters.

The Nuo mask in The Banquet is functioning as a highly symbolic cultural icon. Nuo, which is also named as Da Nuo, was a religious ritual performed in ancient China to expel evil spirits and to call upon deities' benevolence for ensuring good health and good fortune, rich harvests, and long life. Nuo rituals started in Shang and Zhou dynasties, basing on the traditional Chinese philosophical concept that each and every thing has its own spirit. Typical Nuo ritual involves mask application. It was performed by the shaman titled "Fang Xiang Shi." With a mask on his face, a wane in his hand, Fang Xiang Shi, who was regarded as the professional Nuo god, drummed, danced and shouted to expel ghosts and illness. It is recorded in The Book of Rites that "Fang Xiang Shi puts bear skin on his hands, wears gold mask on his face, wields a spear and shield, and commands slaves to expel evil spirits." (Duan \& Shi: 2003) From Shang and Zhou dynasties to Tang and Song dynasties, Nuo rituals and dances were fairly popular in the royal palace. The Nuo drama thus developed from this type of ritual and dance. In Nuo dramas, actors took the place of professional Fang Xiang Shi and acted with masks on their faces. The Nuo masks are "regarded as the living fossils of Chinese ancient dramas for its primitive and fine art craft." (Ma: 2000,36)

The most ready-made and very appropriate application of the Chinese Nuo mask in the film is the displacement of the play-within-the-play in Hamlet with its Nuo drama counterpart in the film. The director chooses to stage the Mousetrap in the form of Nuo drama. For the coronation of Empress Wan, Emperor Li decides to hold a banquet to treat the whole court. The Crown Prince Wu Luan comes with a drum in his hand and a mask on his face. He offers to present a drama for the newly crowned emperor and empress. In place of long speeches in the original text of Hamlet Mousetrap, the Chinese Prince has a man donning in black do some acrobatic dances while giving the simple narration to begin the play_- "Darkness has fallen." (Feng: 2006) And with the beating of drum, a player enters in elaborated and beautiful costume. His pale golden gown has shoulders and sleeves decorated in heroic red. He has gold plates on his bosom and tall red crown with a long feather on top. His liege nobility is well shown in his costume and accessories. On his face is an awe-inspiring mask, with smooth contour and forceful carving. The eyebrows are long and slant. In place of eyes there are merely two fiercelooking small holes. Exaggeratingly shaped nose and mouth make the entire mask ferocious and virile. It is highly noticeable that the mask is heavily painted as bloody red. According to the color coding of Chinese masks, the color red symbolizes courage and brevity, which is usually applied to majestic roles of loyalty, audacity and power. The mask of red is well suited to the player's imperatorial role as the Old Emperor. The player mimes out the Old Emperor's taking a nap in the garden while the second play enters in sheer white. He has no crown on his head. The mask on his face is exactly the same with the former one on the face of the Old Emperor. The only difference is that the mask is also in sheer white, which is usually adopted to denote that the role is crafty and evil, cruel and treacherous at the same time. With the poison 
blown into the ear hole of the Old Emperor, the murder scene is re-enacted. The play ends up with a close-up shot of the dead body in the center of the stage. Prince Wu Luan observes in silence. Feng Xiaogang's choice of masks in general and his choice of mask color in particular are patternized and in accordance with the requirement of the Chinese Nuo drama ritual, presenting a visible image of the personality of the character concerned. Masks in this scene have not only produced the expected theatrical effects, but also added intensity to the expression of the inner world of the two players on stage, and produced at the same time a strong aesthetic effect. In this way, Shakespeare's play-within-the-play in Hamlet thus gains its nicely presented Chinese interpretation.

Apart from the direct adaptation of the Chinese Nuo mask into the film, variations of Nuo mask are used extensively in The Banquet. When the Old Emperor marries Wan, the Crown Prince Wu Luan's childhood lover literally becomes his stepmother. Wu Luan chooses to hide out in mountains of $\mathrm{Wu}$ and Yue area and studies music and dance in a bamboo surrounded gallery. The opening of the film shows $\mathrm{Wu}$ Luan and his peers singing and dancing in the gallery. All students are in sheer white garments, with masks on their faces. The masks are made from gauze, with very simple molding and without any decoration. Eyes and mouth are cut open in their respective positions in order that the mask wearer can see and sing. According to the classification of Chinese Nuo masks, there are three types: masks of the ferocious, masks of the kindhearted, and masks of the absurd. The masks that Wu Luan and his peers wear belong to the type of the kindhearted. Yet these masks to some extend also deviate from Chinese Nuo masks in their simplicity. They are quite similar to neutral masks in the western theater. The neutral mask is usually a single colored leather mask. It is without particular expression and emotion. It does not laugh or cry, nor will it show happiness or sadness. The molding should be simple, peaceful and regular.

The neutral mask is an object with its own special characteristics. It is a face which we call neutral, a perfectly balanced mask which produces a physical sensation of calmness. This object, when placed on the face, should enable one to experience the state of neutrality prior to action, a state of receptiveness to everything around us, with no inner conflict. (Lecoq: 2000, 36)

It is a means to discover, to recognize and to assume the "neutral state" that exists before action, a state of receptivity to the surroundings, a state of balance from which it will be easier to understand and express imbalances and conflicts of characters. This combination of Nuo mask and neutral mask serves well in the opening scenes of the film. The Crown Prince and his peer students put on the mask to perform. Facing white paper scrolls on which there are ancient music scores, the performers sing and dance, surrounded by green mountains and bamboo groves. It is in this sort of life that Wu Luan tries (in vain attempt, though) to be away from the political fights and conflicts in the royal court, to retreat to the hermitage in nature, to abandon himself to music and dance. This shows the Crown Prince's philosophy of inaction instead of action. The white mask radiates a lonely and silent image. By shutting off all the facial expression to communicate emotion, it on the one hand frees any restriction to the body, giving the performer a better capacity to control his own body. The torso and limbs sometimes twist and bend, and sometimes convulsively drop, producing a ritualized dance that is highly mysterious and symbolic, representing dedication and solitude. On the other hand, performers with the same masks and costumes have formed a group that is collective and de-personalized. They are the interconnected mirror statues. It is in this group that there is no distinction of the royal and the civil. No one can tell who the prince is and who is not. There is neither contradiction nor conflicts, neither emotion nor desire. All one can have are music, dance, and an inner equilibrium. When the newly crowned Emperor Li sends out his imperatorial guards 
to assassinate the Crown Prince in order to root out the immediate heir to the throne, the black metallic masks that the guards wear have formed a sharp contrast to the white masks that the performers wear. The former, on the faces of black armored guards who are riding black horses, are cold and lifeless. They have the smell of brutality, cruelty and death. The owners of these masks are mere servants of the royal fights. Hidden under the metal masks, they obey the call of the Emperor to kill. The latter, on the faces of the performers, are calm and tranquil, merging into the soul of the performance. A distinction is established between, on one side, the tranquility and beauty of arts and, on the other, political power and martial action. While the killing begins, the music and dance have not stopped. The Crown Prince is a performer; each performer is the Crown Prince. The depersonalizing masks help Wu Luan survive the assassin.

The white mask as the variation of Chinese Nuo mask continues to function when the Crown Prince successfully returns to the palace. In his backpack there are a music scroll, a sword (the Sword of Yue Maiden) and a mask. The music scroll-something that he brings from his past life, represents his past inaction; the Yue Maiden Sword-something to kill with, represent his future action; and the mask is the go-between of the past and the future. Having gone through the fights and survived the assassin, the white mask is now contaminated and tainted with stains. The soiled mask loses its previous serenity and peace and has a touch of ferocity and hideousness. On most of the occasions, Wu Luan hides himself under the mask. Even when he comes to meet Empress Wan-his teenage year lover, his ex-stepmother and now his royal aunt, he chooses to conceal his face under the mask. For this, he gives his own explanation:

EMPRESS WAN: Why do you wear a mask when you perform?

WU LUAN: It transports an actor to the highest state of his art. Without a mask, happiness, anger, sorrow and joy are simply written on his face. But with a mask, a great artist can convey to the audience the most complex and hidden emotions. (Feng, 2006)

Contrary to his explanation, Wu Luan is trying very hard to hide his emotions, which he would trust revealing to no one and only to be kept by himself. He still has feelings for Wan, though he knows that he can never have her from the time she marries his father, not to mention that now she is the new empress of the kingdom. The mask functions as the screen to cover his interior love as well as the hide to cover his Oedipal desire toward his once lover, ex-stepmother, and the current queen. The mask thus in the first place becomes his second face, his exterior, and his ego. The reason why he is back should not be Wan. He comes back to the kingdom for the purpose of resolving political issues. He is supposed to kill the new Emperor in attempt to revenge his father's death, to regain his usurped throne, to release his hatred on the infidel queen. A mask tainted with a touch of ferocity and hideousness may project an image that he has to possess. Driven by responsibility as a dutiful son to his father and by the ethics as loyal prince to his kingdom, he should "take arms against a sea of troubles, And by opposing end them." (Hamlet, Act III, Scene I) Yet this exterior image required by the social norms is highly contradictory to his interiority - his wish for inaction, peace, and pure art. It is in conflict with his subconscious id. The mask serves as a shield between the exterior ego and interior id, ensuring the inner secretes and desire. By putting the mask on his face, he shuns the reality and retains his state of being an actor in a play. "The play's the thing. Wherein I'll catch the conscience of the King." (Hamlet, Act II, Scene II). In the second place, the mask that conceals the Crown Prince's emotions also serves to protect him. In Hamlet, the motif of spying and surveillance is omnipresent. Hamlet feigns madness to distract from the fact that he is attempting to kill Claudius as revenge. Being calculating and suspicious, saying that "It shall be so: Madness in great ones must not unwatch'd go." (Hamlet, Act III, Scene II) Claudius has 
sent Hamlet's love Ophelia spying on him while he and Polonius hide and eavesdrop behind. Hamlet's fellow students Rosencrantz and Guildenstern are also commissioned to spy on the prince. After the play-within-the-play, the prince spies on Claudius when he is praying, only to find later that he is spied by Polonius in his mother's closet. In The Banquet, the motif of spying and surveillance is well retained. During the whole process of Wu Luan and Empress Wan's first encounter, Emperor Li hides and secretly watches. Yet by having Wu Luan putting on his mask on most of the occasions, the director uses mask to displace the prince's feign of madness. While the mask protects its wearer from spying and surveillance, it nevertheless attracts attention by creating an air of absurdity. This soiled mask in The Banquet enables Wu Luan to observe without being watched, yet at the same time it also draws discerning gaze from the secrete observer surrounding him. Its double function of disguise and attraction places the prince in the dilemma of being gazed and not being gazed, thus offering the film a symbolic approach to dim the theme of revenge and to highlight the internal struggle.

Another variation of the Chinese Nuo mask is the copper carved mask that symbolizes the Old Emperor's ghost. Different from the source text of Hamlet, the Ghost has not appeared at midnight to unfold his brother's crime and urged the prince to "revenge his foul and most unnatural murder." (Hamlet, Act I, Scene V) In The Banquet, the Old Emperor makes no appearance. The only memory of him comes from a standing armor in a courtroom, which he wore to kill in the battlefield. Under the bronze helmet is a copper carved mask. Since the owner of this mask has long deceased, in part where the eyes exist are now merely two empty holes. This mask deviates from the traditional Nuo mask in it metallic quality and carving. Yet the essence of the Nuo mask is still retained. Many nations in the world hold the belief that a spirit can reside in a mask. The spirit might be a god, an ancestor or the spirit of a place or inanimate object. The mask thus often represents a connection with the spiritual world. Ancient Chinese also believed that a Nuo mask can hold the soul of the newly deceased. In this sense, it is fully natural that the director adopts this copper mask as the incarnation of the Old Emperor's ghost. Audience can see that while Emperor Li and Empress Wan are consummating their wedding night, naked and tangled in heated incestuous desire, the mask sheds bloody tears to the mourning Crown Prince. The enliven mask now fully takes the place of the ghost, raged by Emperor Li's usurpation, grieved over Wan's incestuous marriage, consoled by the Crown Prince's return. The necessity and urge of revenge are in the air.

Though the adoption of masks can be found everywhere in the film, two roles are seldom seen with masks. The only literal masks that Emperor Li and Empress Wan wear are his black metal mask and her floral patterned leather mask when they are playing hockey on horse back. Yet these masks are more of decorative function than symbolic denotation. Empress Wan has once criticized Wu Luan's absurdity of hiding himself behind the mask:

You are incapable of even the most basic play-acting. Your sorrow, anger, bitterness, and uncertainty are there for all to see. You permit danger to follow you everywhere. You think hiding behind the mask can elevate your art? The highest level is to use your own face and turn it into a mask. (Feng, 2006)

Perhaps for the most cautious and scheming politicians, putting on a mask to hide the true interior feelings seems futile and tactless, making one's real face as the mask and creating an entirely different outer self is a better strategy to survive in the palace. That is the reason why Wan marries and remarries for her position as the queen despite of the hatred of the two emperors' greed and lust, and why she can be strong-willed to poison Li for her throne despite of the newly kindled feeling for him. That is the reason why Li can applaud for the prince when 
realizing that his crime is revealed. Yet the tragedy lies in the fact that with or without masks, desire and ambition ruin them all.

Feng Xiaogang's The Banquet, with its huge box office income and critical attention, indebts its success to the wonderful merge of the Chinese and western culture. The original and skillful appropriation of the Chinese Nuo masks in the film contributed to the success. It is only one example in the process of the intercultural film adaptation of the western classic. It explores the connections between the two cultures and challenges the transfer of a Chinese cultural icon into a western play. The significance of the intercultural adaptation of Shakespeare lies in the process through which Shakespeare has come to embody even greater cultural value, and broader range of such value that his work can conceivably encompass. The combination of Shakespeare, China, and the most popular medium in the mass media provides the marriage of the highest kind of entertainment with high educative, aesthetic, as well as cultural value. By adapting Shakespeare in a global and intercultural context, the Bard's cultural afterlife can still be exploited in even more vivid and more creative ways. A thousand ages have a thousand Shakespeares. A thousand countries interpret a thousand Hamlets. For your Hamlet is not our Hamlet.

\section{WORKS CITED:}

BLOOM, Harold. The Western Canon: The Books and School of the Ages. New York: Riverhead Books, 1994.

DUAN, Wei and Shi Kun. "Nuo, Nuo Mask, Nuo Ritual and Nuo Culture." Chinese Ancient Crafts. 20030604.

(段微, 石昆, “傩·傩面·傩祭.傩文化”，中国文物报，20030604，第 5 版。)

LECOQ, Jacques, with CARASSO, Jean-Gabriel and LALLIAS, Jean-Claude. The Moving Body: Teaching Creative Theatre. Translated by David Bradby. London: Methuen, 2000.

JIA, Leilei. A History of Chinese Martial Arts Films. Beijing: Culture and Arts Publishing House, 2005.

(贾否否, 《中国武侠电影史》, 文化艺术出版社, 2005。)

MA, Shutian. Gods in China: Ghosts and Spirits. Taibei: Yunlong Press, 2000.

(马书田, 《华夏诸神——鬼神卷》, 台北: 云龙出版社, 2000。)

SHAKESPEARE, William. Hamlet, Prince of Denmark. Ed. David Bevington. The Complete Works of Shakespeare. $4^{\text {th }}$ ed. London: Harper Collins Publishers, 1992. 1060-1116.

Zhang Ying holds the position of associate professor in English Department, School of Foreign Studies, Nanjing University. A young scholar in Shakespeare studies and film adaptation studies in China, on which she has published a book and several papers in well-known Chinese literary journals. She has also completed the project of "Shakespearean Intercultural Performance and Adaptation in Contemporary China" granted by the Department of Education in China. For further information see https://sfs.nju.edu.cn/10740/list.htm

Submetido em 05/05/2020

Aprovado em 15/06/2020 